\title{
Effects of Arctic Alaska Oil Development on Brant and Snow Geese
}

\author{
JOE C. TRUETT, ${ }^{1}$ MARK E. MILLER ${ }^{2}$ and KENNETH KERTELL ${ }^{3}$
}

(Received 4 August 1996; accepted in revised form 25 February 1997)

\begin{abstract}
Black brant (Branta bernicla nigricans) and lesser snow geese (Chen c. caerulescens) breeding in and near arctic Alaska oil fields could be affected by oil development actions such as releases of contaminants, alteration of tundra surfaces, creation of impoundments, and human activities. These actions could affect geese directly (e.g., through oil spills) or indirectly (e.g., by altering food supplies or predator populations). Studies to date indicate no changes in the distribution, abundance, or reproduction of these geese that clearly can be attributed to development; rather, their numbers and recruitment have responded in the oil fields, as elsewhere, mainly to weather and predation. When snowmelt in spring is later than usual, the birds postpone or forego nesting, with consequent diminishment in recruitment. Predation by arctic foxes (Alopex lagopus), glaucous gulls (Larus hyperboreus), and grizzly bears (Ursus arctos) sometimes causes substantial losses of eggs and young, and predation by ravens (Corvus corax) has also been observed. Development-related changes in weather (microclimate) and loss of feeding habitat have involved small percentages of the total areas traditionally used, and populations of the birds probably have not been affected by these changes. Some studies and observations suggest that development has elevated local populations of some predators, but whether the level of predation on geese has in consequence risen above that which would have occurred in the absence of development is unknown; further investigation of this mechanism of potential impact is recommended.
\end{abstract}

Key words: Brant, Branta bernicla, snow goose, Chen caerulescens, oil development, Alaska, impact assessment, predation, nutrition

RÉSUMÉ. La bernache noire (Branta bernicla nigricans) et la petite oie des neiges (Chen c. caerulescens) nichant dans les champs pétrolifères de l'Alaska ou à proximité pourraient être affectées par des actes reliés à l'exploitation pétrolière, tels que le déversement d'agents de pollution, les modifications à la toundra de surface, la création de bassins, et par l'activité humaine. Ces interventions pourraient affecter les oies de façon directe (p. ex., par le biais de déversements de pétrole) ou indirecte (p. ex., en modifiant l'approvisionnement alimentaire ou les populations de prédateurs). Jusqu'à l'heure actuelle, les études ne montrent pas de changements dans la distribution, l'abondance ou la reproduction de ces oies, dont la cause puisse être clairement attribuée à l'exploitation; dans les champs pétrolifères, le nombre d'oies et leur augmentation ont surtout réagi, comme ailleurs, au climat et à la prédation. Quand la fonte des neiges printanière a lieu plus tard que d'habitude, les oiseaux retardent la ponte ou s'abstiennent de pondre, ce qui entraîne moins d'augmentation. La prédation par le renard arctique (Alopex lagopus), le goéland bourgmestre (Larus hyperboreus) et le grizzli (Ursus arctos) entraîne parfois d'importantes pertes d'oeufs et d'oisons, et on a également observé des cas de prédation par le corbeau (Corvus corax). Des modifications climatiques (microclimat) reliées à l'exploitation et la perte d'aires d'alimentation ne concernent qu' un faible pourcentage du total des zones utilisées traditionnellement, et les populations d'oiseaux n'ont probablement pas été affectées par ces changements. Quelques études et observations suggèrent que la mise en valeur a fait augmenter les populations locales de certains prédateurs, mais on ne sait pas si le niveau de prédation de l'oie qui en a résulté était plus élevé qu'il ne l'aurait été en l'absence de la mise en valeur; on recommande que le mécanisme de ces retombées potentielles soit étudié plus à fond.

Mots clés: bernache cravant, Branta bernicla, oie des neiges, Chen caerulescens, exploitation pétrolière, Alaska, évaluation environnementale, prédation, nutrition

Traduit pour la revue Arctic par Nésida Loyer.

\section{INTRODUCTION}

Following discovery of oil at Prudhoe Bay in 1968, petroleum development expanded in that part of northern Alaska. Concurrently, concerns escalated about the potential impact of oil development on wildlife and wildlife habitat in the oil-field area (Walker et al., 1987), and numerous studies to assess effects on wildlife were conducted (Maki, 1992). Migratory waterbirds were the focus of many such studies because of their perceived vulnerability to development (Vermeer and Anweiler, 1975; Sargeant and Raveling, 1992).

Most oil development activities in northern Alaska cluster on the arctic coastal plain near the Beaufort Sea. Consequently, much research has focused on waterfowl species

\footnotetext{
${ }^{1}$ Truett Research, P.O. Box 211, Glenwood, New Mexico 88039, U.S.A.; jjtruett@ worldnet.att.net

${ }^{2}$ Department of Geography, University of Colorado, Boulder, Colorado 80302, U.S.A.

${ }^{3}$ SWCA Inc., Environmental Consultants, 343 S. Scott Avenue, Tucson, Arizona 85701, U.S.A.

(C) The Arctic Institute of North America
} 
known to feed and breed in predominantly coastal areas. Two colonially nesting geese, black brant and lesser snow goose, have attracted attention from impact analysts because of their proximity to the development area during the summer breeding season.

Several hundred to a thousand or more black brant breed each year in the vicinity of northern Alaska oil fields (Johnson, 1994a; Stickney and Ritchie, 1996). Though this population represents only a small proportion of the 50000 or so black brant nesting in Alaska (Sedinger et al., 1993), most of the population nest and feed in coastal areas vulnerable to oil development impacts (Kiera, 1984; Stickney and Ritchie, 1996). Brant numbers in Alaska have declined precipitously in recent decades (Sedinger et al., 1993), though the population in and near arctic Alaska oil fields has remained relatively stable (Stickney and Ritchie, 1996).

A snow goose nesting colony in the Sagavanirktok River delta near Prudhoe Bay contains the majority of breeders (several hundred pairs) of this species in Alaska. Families from this colony feed in coastal areas in and near oil fields (Johnson, 1994b). Though this colony is small in relation to the total snow goose population, it is of interest because it is the only North American colony of more than a few birds that nests outside Canada (Johnson, 1994b).

This paper explores the mechanisms and extent of impacts of oil development on brant and snow geese in northern Alaska. It relies heavily on the results of published and unpublished studies conducted in and near the oil fields.

\section{POTENTIAL IMPACT MECHANISMS}

Development of the Prudhoe Bay Oil Field began in 1969, and the field came into production in 1977. Since then, five additional oil fields (Kuparuk, first oil produced in 1981; Milne Pt., 1985; Endicott, 1985; Lisburne, 1986; and Pt. McIntyre, 1994, see Fig. 1) and several smaller accumulations have been brought into production in the Prudhoe Bay region. Aspects of development that could have affected geese include release of contaminants, alteration of the tundra surface, creation of impoundments, and other human activities. Both direct effects (e.g., from disturbance) and indirect effects (e.g., from alteration of food supplies or predator populations) could have resulted.

\section{Release of Contaminants}

Crude oil, chemicals, seawater, and other materials released on the tundra potentially may degrade or destroy vegetation in goose habitat. However, the magnitude of all classes of contaminants spilled in the oil-field region is small, as exemplified by data from the Prudhoe Bay Oil Field (Table 1). A spill of $48000-95000 \mathrm{~L}$ of crude oil and produced water in the Kuparuk Oil Field in late summer 1989 contaminated 0.58 ha (Jorgenson and Cater, 1992). Applying this volume-to-area ratio to Table 1 suggests that the proportion of oil-field acreage encompassed by all accidental spills has been a small fraction of $1 \%$. Further, far less than $10 \%$ of these spills, both by number and by volume, reach the tundra; most occur on gravel roads and pads or in specially built containment areas, or on snow and ice in winter, so that they can be removed before reaching the substrate (M. Gilders and C. Herlugson, BP Exploration [Alaska] Inc., pers. comm. 1996).

In the past, muds, cuttings, and other by-products of drilling operations were released into specially constructed reserve pits at drill sites (ENSR, 1992). A few hundred such pits exist in the oil-field region-the two major operators (BP Exploration and ARCO, Alaska) report having constructed 262 reserve pits as of early 1996 (M. Gilders, BP Exploration [Alaska] Inc., pers. comm. 1996). The habitat acreage lost to reserve pits is included below in the estimated acreage lost to gravel fill. Currently, drilling by-products are injected into subsurface formations rather than deposited in surface pits.

The potential for the drilling contaminants to have affected geese directly is remote. They occur in non-toxic concentrations (ENSR, 1992), and geese have not been reported (or expected) to consume them or get appreciable amounts on their bodies.

\section{Alteration of the Tundra Surface}

Roads, production and processing facilities, and other support structures in northern Alaska oil fields are constructed on ribbons and "pads" of gravel fill 1-2 m thick (Walker et al., 1987), which insulate and stabilize the underlying permafrost. In the Prudhoe Bay Oil Field (Fig. 2), the oldest and most densely developed of the fields, approximately 2156 ha were covered by gravel pads, roads, or gravel excavation sites as of 1986 (Senner, 1989). This accounts for about $2.3 \%$ of the 92876 ha oil-field unit. In the more recently developed Kuparuk Oil Field, gravel and gravel excavation sites covered approximately 1012 ha of the 130637 ha unit near the completion of its development in 1986 , or about $0.8 \%$ of the landscape (Jorgensen, 1988). The relatively small proportion of gravel coverage in the Kuparuk and other recently developed oil fields can be attributed primarily to a less redundant road network, to recent improvements in directional drilling techniques, and to recent elimination of reserve pits.

Tundra surfaces not insulated with gravel are subject to other kinds of alteration. During exploration leading to the 1968 discovery of oil, roads for cross-tundra travel were commonly constructed by mounding and grading the peaty surface soil or by blading aside the surface soil to reach the underlying permafrost. Over time such disturbances caused thermokarst, i.e., surface subsidence resulting from the thawing of ice-rich tundra soils (Mackay, 1970). Other development-related surface disruptions that have caused thermokarst include dust deposition adjacent to gravel roads (Walker and Everett, 1987) and movement of vehicles or other heavy equipment across the tundra. The latter has declined greatly since the early 1970 s, when government regulations were enacted to restrict vehicular travel on the 


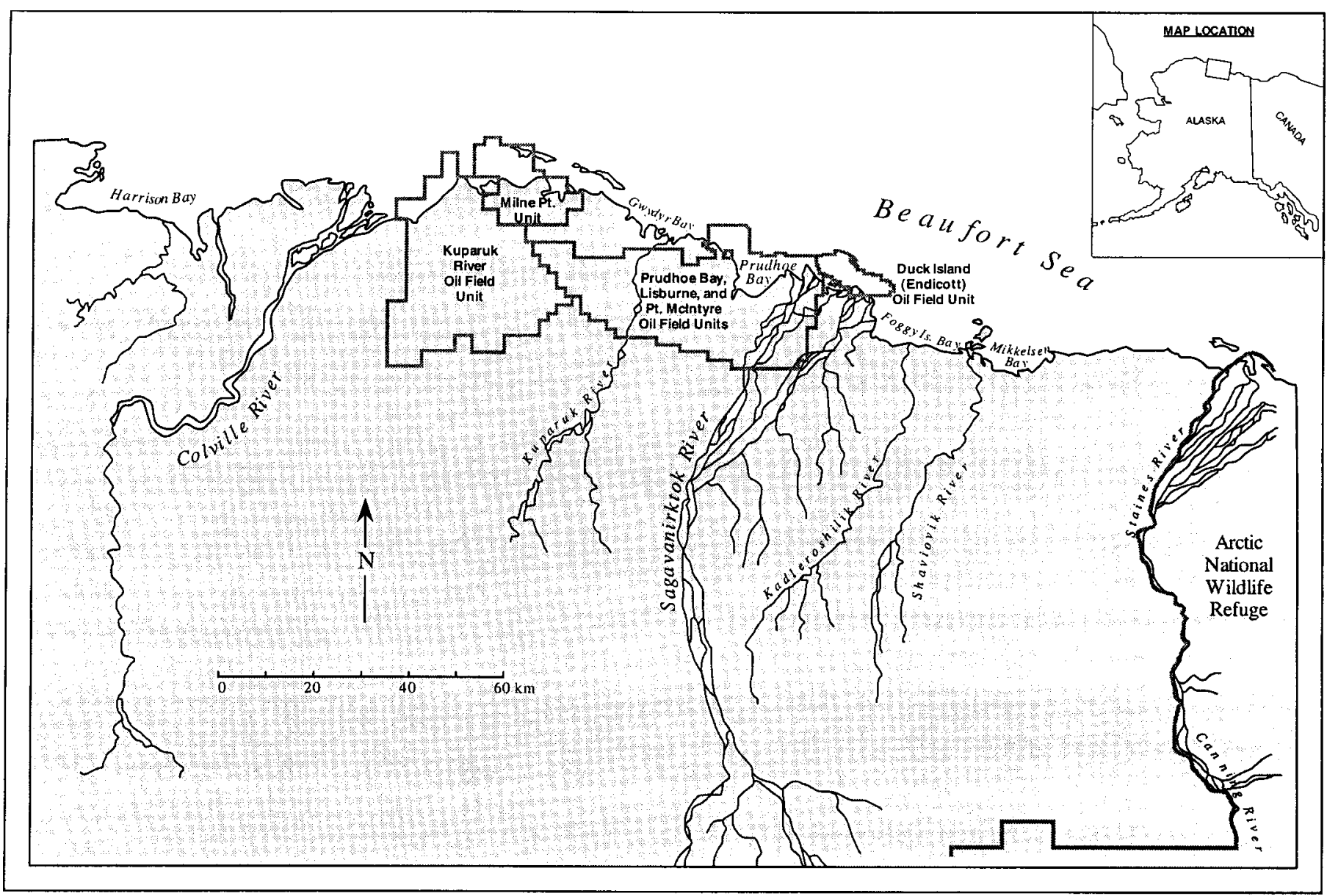

FIG. 1. Producing oil fields in northern Alaska, 1996. Adapted from a map provided by BP Exploration (Alaska) Inc., Anchorage.

tundra. As of 1983, approximately $3.6 \%$ (74 of 2088 ha) of the most intensively developed portion of the Prudhoe Bay Oil Field had been influenced by thermokarst or other nongravel surface disturbances associated with development (Walker et al., 1986).

\section{Creation of Impoundments}

Impoundments, defined as artificial water bodies created by alteration of natural drainage patterns, have been formed in the oil fields where gravel roads and pads block surface flow of meltwater in summer. Impounded water reduces surface albedo, thereby causing thermokarst, which enlarges some impoundments until a new thermal equilibrium is attained (Lawson, 1986). Walker et al. (1986) estimated that impoundments in 1983 covered about $19.7 \%$ (411 of 2088 ha) of the landscape in an intensively developed portion of the Prudhoe Bay Oil Field. Noel et al. (1996) calculated that about $0.9 \%$ ( 800 of 92876 ha) of the entire Prudhoe Bay Oil Field was covered by impounded floodwater in mid-July 1993; of this area, 75\% was flooded for only a portion of the summer. Because the Prudhoe Bay Oil Field is located in an exceptionally flat and poorly drained part of the coastal plain (Walker et al., 1986), impoundments cover proportionately more of its land area than they cover in the other oil fields.

\section{Human Activities}

Human activities that could affect brant and snow geese include the construction and operation of facilities, movement of vehicles on roads and at facilities, people moving about on the tundra, and waste disposal. Movement of people and machines exerts its greatest potential influence by disturbing birds or obstructing their movements; direct mortalities are uncommon. Discarded food wastes potentially attract omnivorous scavengers that may prey on waterfowl. Food wastes generated in the oil-field region are bagged and stored temporarily in dumpsters adjacent to camp facilities, then are removed to a landfill (scheduled to close soon) located within the Prudhoe Bay Oil Field. Some wastes are incinerated to ash before being deposited in the landfill, and some are not (C. Herlugson, BP Exploration [Alaska] Inc., pers. comm. 1996).

\section{APPARENT IMPACTS: CHANGES IN BIRD} DISTRIBUTION, ABUNDANCE, AND REPRODUCTION

\section{Brant}

Brant arrive in northern Alaska in late May or early June and move quickly to nesting areas (Johnson and Herter, 
TABLE 1. Number and volume of liquid contaminant (oil, other chemicals, and seawater) spills in the Prudhoe Bay Oil Field, 1990-94 (Data from M. Gilders, BP Exploration [Alaska] Inc., pers. comm. 1995).

\begin{tabular}{ccc}
\hline \hline Year & Number & Volume (liters) \\
\hline 1990 & 920 & 244671 \\
1991 & 930 & 1695328 \\
1992 & 669 & 176396 \\
1993 & 657 & 523993 \\
1994 & 591 & 43030 \\
\hline \hline
\end{tabular}

1989), most of which are on islands in coastal lakes and river deltas (Kiera, 1984; Stickney and Ritchie, 1996). Several hundred pairs of brant nest between the Colville and Canning Rivers; the two largest colonies are (1) on Howe and Duck Islands in the Sagavanirktok River delta near the large Endicott Development Project, and (2) in the Kuparuk River delta (Stickney et al., 1993; Johnson, 1994a; Stickney and Ritchie, 1996) (see Fig. 2). Brant numbers have varied considerably from year to year at specific nesting colonies and broodrearing areas, but there is no evidence that these changes have been caused by oil development activities (Stickney and Ritchie, 1996). For instance, oil development in the Sagavanirktok River delta began in 1984 with commencement of the Endicott Project. The nesting population of brant in the vicinity of this development increased more than fourfold during the construction period (1984-90). The population declined during 1991-94, but for reasons not attributed to development (Johnson, 1994a, 1995).

\section{Snow Goose}

Snow geese usually arrive in the Sagavanirktok River delta in the last week of May and settle on Howe Island to nest in early June (Johnson and Herter, 1989). Some snow geese have nested on smaller islands, or on the nearby mainland, especially in years of below-average spring temperatures and years when predators have inhabited Howe Island (Johnson, 1994b). After eggs hatch in late June and early July, the geese quickly move with their broods to sedge marsh feeding areas, mainly in the Sagavanirktok delta but also at coastal locations west and east of the delta. In 1993, brood-rearing areas extended up to $20 \mathrm{~km}$ west, $35 \mathrm{~km}$ east, and $10 \mathrm{~km}$ inland of Howe Island (Johnson, 1994b).

Intensive studies of the Howe Island colony during nesting and brood-rearing (Johnson 1994b; 1995) disclosed no distributional changes caused by the Endicott Development Project. Geese not only nested on Howe Island both before and after the Endicott causeway passed within three $\mathrm{km}$ of the island, but during some post-development years, they nested even nearer to the heavily trafficked causeway corridor than they had prior to development. Preand post-nesting geese also continued to use sites adjacent to the development activity, and broods of young routinely crossed the Endicott road/causeway to reach traditional broodrearing areas and to establish new ones.
The post-nesting population of Sagavanirktok delta snow geese increased tenfold during 1980-90, primarily because of consistently high annual reproductive success. Major declines in productivity occurred in 1991, 1992, and 1994 (Johnson, 1994b, 1995). During the five-year period following the initiation of the Endicott Project, the growth rate of the goose population remained about the same as it had been during the five years preceding development. The reproductive failures in 1991, 1992, and 1994 were not associated with changes in development activity.

\section{CRYPTIC IMPACTS: THE ALTERATION OF HABITAT}

Three habitat factors that could be influenced by oil development - weather, predation, and food deficiencieshave been implicated in limiting goose survival and reproduction in arctic breeding areas (Ankney et al., 1991; Sargeant and Raveling, 1992). Below we evaluate evidence that oil development in arctic Alaska may have altered weather, predator populations, or food availability so as to affect brant or snow goose populations.

\section{Weather-related Impacts}

Cold weather and the associated persistence of snow in spring on breeding grounds often causes nesting delays and reduced productivity in brant (Barry, 1962; Reeves et al.,1976; Ankney, 1984; Summers and Underhill, 1987) and snow geese (Boyd, 1982; Boyd et al., 1982; Davies and Cooke, 1983; Cooke et al., 1984). Oil development in arctic Alaska ameliorates the impact of weather locally by causing an acceleration in spring snowmelt near heavily trafficked roads. Dust from traffic settles on snow, decreases albedo, and causes snowmelt up to $100 \mathrm{~m}$ downwind of the road as early as 10-14 days before general melt-off (Walker and Everett, 1987).

Brant and snow geese in the oil fields sometimes preferentially occupy this early-melt dust shadow of oil-field roads prior to nesting (Burgess et al., 1990; Murphy and Anderson, 1993; Anderson and Cooper, 1994). But because roads do not pass near nesting colonies, it is unlikely that this melt-off hastens nest initiation. Even if geese find better food in the melt-off areas, potentially gaining a nutritional advantage, a small increase in the food supply is unlikely to translate into measurable improvements in recruitment, as will be discussed later.

\section{Impacts on Predator Populations and Predation}

Predation, often by arctic foxes and/or glaucous gulls on eggs and young, can cause major reductions in recruitment of brant (Eisenhauer, 1977; Petersen, 1982; Raveling, 1989; Anthony et al., 1991; Sedinger et al., 1993) and snow geese (MacInnes and Misra, 1972; Syroechkovskiy et al., 1991; Sargeant and Raveling, 1992). In arctic Alaska, oil development may have affected densities of some predators that are 


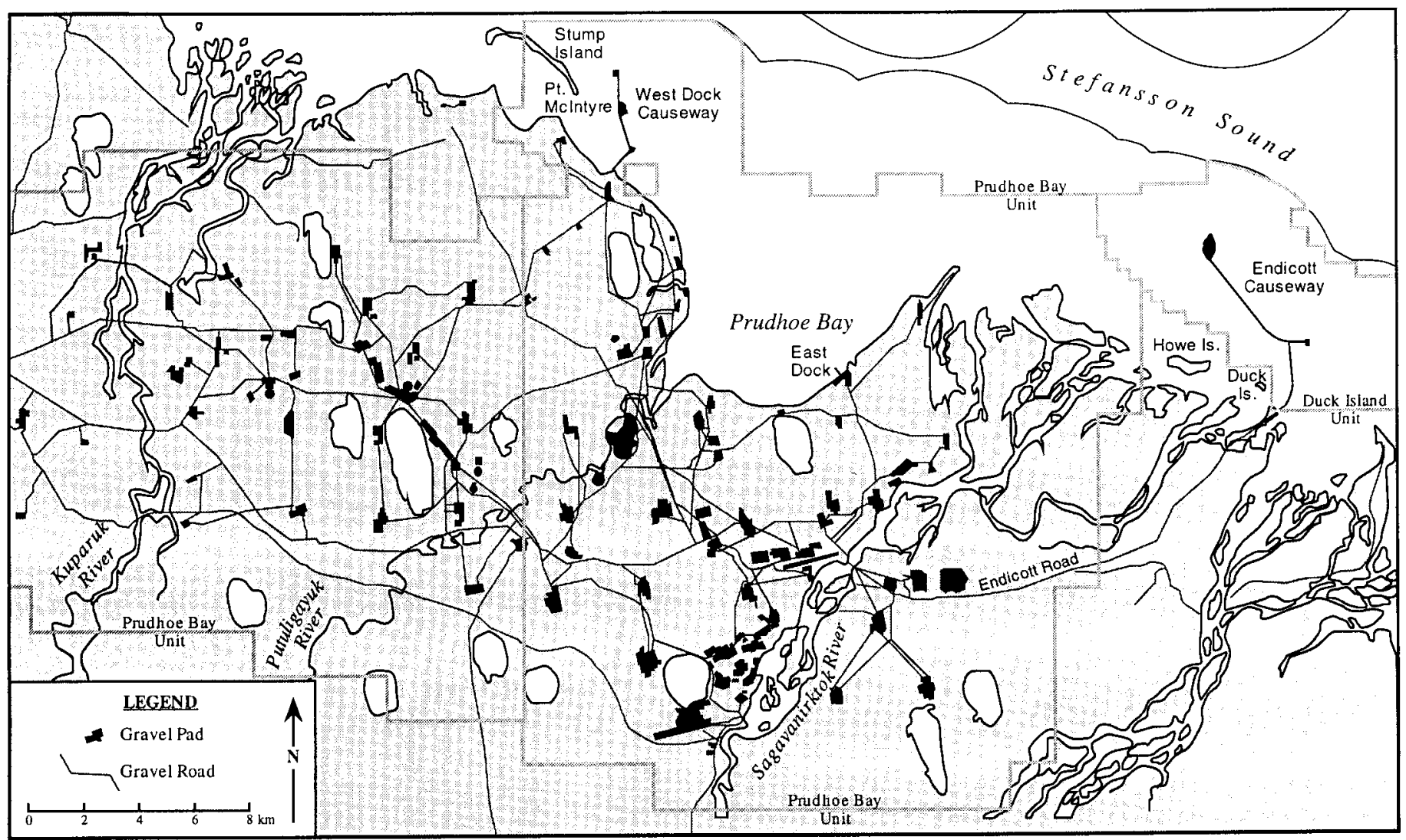

FIG. 2. The most intensively developed portion of the northern Alaska oil fields, centered on the Prudhoe Bay Unit. Adapted from a map provided by BP Exploration (Alaska) Inc., Anchorage.

known to prey on geese. Four species-arctic fox, glaucous gull, grizzly bear, and common raven-are potentially implicated.

Development probably has benefitted arctic foxes by providing food subsidies (garbage) and denning sites (Burgess et al., 1993). Eberhardt et al. (1983) found the density of arctic fox dens in the Prudhoe Bay oil-field area to be about three times that in the undeveloped Colville River delta west of the oil fields. The oil-field fox population also was more dense and underwent less dramatic fluctuations than that in the Colville delta (Eberhardt et al., 1982). Likewise, Burgess et al. (1993) found a greater density of fox dens and breeding foxes in developed than in undeveloped portions of the Prudhoe Bay region; they found pup survival to be highest in areas of high-density development. (The absence of temporal controls in these studies weakens the inference that oil development always caused the observed differences between developed and undeveloped areas.)

Some studies elsewhere show a direct relationship between arctic fox density and losses of waterfowl eggs. MacInnes and Misra (1972) reported that near Hudson Bay, the losses of Canada goose (Branta canadensis) nests to arctic foxes increased with fox density. Petersen (1982) noted the increased predation loss of Canada goose and black brant nests at Kokechik Bay, Alaska, with increases in arctic fox density. Sargeant and Raveling (1992) attributed increased losses of goose nests (several species) on the Yukon-
Kuskokwim delta, Alaska, at least partly to increases in the arctic fox population.

Fox predation is known to influence substantially brant and snow goose nesting success in arctic Alaska oil fields. Stickney et al. (1993) attributed reduced nesting success by brant in the oil-field region in some years mainly to foxes. Johnson (1994a) identified foxes as the primary cause of brant nest failure in the Sagavanirktok River delta in 199193, and Johnson (1994b) blamed primarily foxes for major snow goose nest failures on Howe Island in 1991 and 1992. The main factor leading to these losses appeared to be easierthan-usual access by arctic foxes to the nesting islands (usually caused by late thaw) rather than development-related changes in the fox population.

Glaucous gulls also take eggs and young of geese in the oil fields and, in comparison with foxes, have easier access to island-nesting birds. Murphy et al. (1986) documented the total loss of eggs in a brant nesting colony near Prudhoe Bay, apparently to glaucous gulls. Johnson (1994b), who observed glaucous gulls preying on snow goose goslings leaving the Howe Island colony in 1993, suspected that gull predation killed a substantial percentage of the young geese that year. It is generally believed that oil development in northern Alaska has led to a local increase in glaucous gulls. Gulls commonly congregate to feed at municipal dumps and other sites of human activity where waste food sources exist (Johnson and Herter, 1989). Murphy and Anderson (1993) reported 
that glaucous gull numbers were much higher within $20 \mathrm{~km}$ of the North Slope Borough landfill near Prudhoe Bay (the only landfill in the oil-field area) than they were $20-40 \mathrm{~km}$ away from the landfill.

Increases in gull densities may exacerbate predation losses in waterfowl. Dwernychuk and Boag (1972) correlated mortality levels in Alberta ducklings (several species) with ring-billed gull (Larus delawarensis) and California gull (L. californicus) densities; duckling survival declined to zero at maximum gull densities. Milne and Reed (1974) attributed most losses of common eider (Somateria mollissima) eggs in St. Lawrence estuary nesting colonies to herring gulls (L. argentatus) and great black-backed gulls (L. marinus); losses increased with gull density. Choate (1967) found common eider nesting success in Penobscot Bay, Maine, to be inversely correlated with the density of herring and blackbacked gulls. Whether increases in glaucous gull abundance in the oil fields of northern Alaska have resulted in increased losses of brant or snow geese eggs or young is unknown.

Grizzly bear populations have increased in the oil fields since development began, but also have increased elsewhere in arctic coastal Alaska during the same period. Bears in and near oil fields show evidence of better nutrition-greater adult weights and larger litter sizes — and perhaps a greater density than those elsewhere in arctic Alaska, presumably because they are subsidized by development-generated refuse (R. Shideler, Alaska Dept. Fish and Game, pers. comm. 1996). Several investigators have reported bears preying on goose nests (and other waterfowl nests) in the oil fields (Johnson, 1995; Stickney and Ritchie, 1996; R. Shideler, Alaska Dept. Fish and Game, pers. comm. 1996). Whether bear predation on brant and snow geese has increased because of oil development has not been quantitatively assessed.

Common ravens currently nest and forage in the oil-field region, but never nested and were seldom present in the area prior to oil development (Johnson and Herter, 1989; S.R. Johnson, LGL Ltd. Environmental Research Associates, pers. comm. 1996). Three pairs of ravens nesting on development structures in the Endicott Oil Field in the Sagavanirktok River delta in 1995 fed their young daily on goose and other waterfowl eggs and on garbage from oil-field dumpsters (S.R. Johnson, LGL Ltd. Environmental Research Associates, pers. comm. 1996). Given the reasonable assumption that these birds would not have nested in the oil fields in the absence of the structures, this predation loss is attributable to development. The level of its effect on brant and snow goose nest success is unknown.

\section{Impacts on Food Availability}

Inadequate nutrition of brant prior to and during egglaying (Ankney, 1984) and of snow geese prior to egg-laying (Ankney and MacInnes, 1978) can curtail their reproductive output, and inadequate nutrition of brant (Sedinger and Flint, 1991) and snow goose (Cooke et al., 1995) broods may reduce gosling growth and thus long-term recruitment. Whether oil development in arctic Alaska has diminished the quality or quantity of the food resource sufficiently to adversely affect brant or snow goose productivity and recruitment depends on (1) the predevelopment adequacy of the forage with respect to needs of the goose populations and (2) the proportion of the food base lost to development.

Much evidence suggests that food may be superabundant in the oil-field region with respect to nutritional needs of the brant and snow goose populations. Weights of given-age brant goslings in the oil-field region are greater than those reported elsewhere, indicating superior nutrition (J.S. Sedinger, Institute of Arctic Biology, unpubl. data). Snow goose densities on the brood-rearing areas of the Howe Island colony are at least an order of magnitude lower than densities in brood-rearing areas of some snow goose colonies in Canada (Johnson et al., 1985), but food production and quality in the Alaskan and Canadian areas probably are roughly comparable (Harwood, 1977).

With respect to snow geese, grazing in the densely populated Canadian colonies has severely damaged the vegetation (Kerbes et al., 1990; Cooke et al., 1995; Ankney, 1996), but even so the reproductive rates have been little affected (Kerbes et al., 1990; Cooke et al., 1995). Similarly severe habitat impacts have not been reported for brood-rearing areas in northern Alaska; thus, food shortages caused by habitat loss seem unlikely. Finally, evidence of large fluctuations in snow goose recruitment in response to weather and predation (presented earlier) suggests that food scarcity per se is secondary to these factors in affecting oil-field populations of these birds.

Not only has the proportion of the goose food base in the oil fields affected by development been small, but food quality and/or quantity in some affected areas may have been improved over their original condition. McKendrick (1986) observed grasses that were planted on gravel fill on the National Petroleum Reserve in northern Alaska being selectively grazed by geese 1-3 years after seeding. Truett and Kertell (1992) concluded that mechanical disruptions of the tundra surface often have led to improvements of rather than declines in the net productivity of plants commonly eaten by geese.

\section{CONCLUSIONS AND RECOMMENDATION}

Oil development in arctic Alaska has caused no apparent changes in the distribution, abundance, or productivity of black brant or snow geese. Since development began, annual distributional shifts within populations of both species, and increases in the abundance of snow geese, have been documented, but none of these changes bear a clear relationship to development.

Weather, predation, and food availability may affect arctic-nesting geese; among these, predation alone has the potential to be altered substantially in its effect by oil development in arctic Alaska. Three known predators of brant and snow geese-arctic foxes, glaucous gulls, and grizzly bears-may have increased in abundance because of development. A 
fourth - the common raven - has recently established a small nesting population, apparently because of development, and birds from this population have preyed on goose eggs. Studies elsewhere have shown that increases in predator populations sometimes cause increases in losses of waterfowl eggs and young. Whether oil development has exacerbated annual predation losses in black brant and snow goose populations in arctic Alaska oil fields is currently unknown.

We recommend that biologists and impact analysts studying brant and snow geese in the oil-field region focus more attention on development-related changes in predator populations and the impacts of these changes on recruitment of young into the goose populations.

\section{ACKNOWLEDGEMENTS}

We gratefully acknowledge financial support from BP Exploration (Alaska) Inc. (BP). Michelle Gilders and Chris Herlugson of BP's Environmental and Regulatory Affairs Department helped conceive this project. They provided encouragement and unpublished reports, and Steve Lombard of BP provided maps. Stephen R. Johnson of LGL Limited provided important unpublished literature and papers in press and gave important comments on a previous draft of this paper. James S. Sedinger of the Institute of Arctic Biology, University of Alaska, also gave helpful review comments on a previous draft. Richard Shideler of the Alaska Department of Fish and Game shared information about grizzly bear populations in the oil-field region.

\section{REFERENCES}

ANDERSON, B.A., and COOPER, B.A. 1994. Distribution and abundance of spectacled eiders in the Kuparuk and Milne Point Oilfields, Alaska, 1993. Unpubl. report. Available at ARCO Alaska, Inc., P.O. Box 100360, Anchorage, Alaska 99510, U.S.A.

ANKNEY, C.D. 1984. Nutrient reserve dynamics of breeding and molting brant. Auk 101:361-370.

1996. An embarrassment of riches: Too many geese. Journal of Wildlife Management 60:217-223.

ANKNEY, C.D., and MacINNES, C.D. 1978. Nutrient reserves and reproductive performances of female lesser snow geese. Auk 95:459-471.

ANKNEY, C.D., AFTON, A.D., and ALISAUSKAS, R.T. 1991. The role of nutrient reserves in limiting waterfowl reproduction. Condor 93:1029-1032.

ANTHONY, R.M., FLINT, P.L., and SEDINGER, J.S. 1991. Arctic fox removal improves nest success of black brant. Wildlife Society Bulletin 19:176-184.

BARRY, T.W. 1962. Effect of late seasons on Atlantic brant reproduction. Journal of Wildlife Management 26:19-26.

BOYD, H. 1982. Influence of temperature on arctic-nesting geese. Aquila 89:259-269.

BOYD, H., SMITH, G.E.J., and COOCH, F.G. 1982. The lesser snow geese of the eastern Canadian Arctic: Their status during
1964-79 and their management from 1981 to 1990. Canadian Wildlife Service Occasional Paper No. 46. 23 p.

BURGESS, R.M., ROSE, J.R., BANYAS, P.W., and LAWHEAD, B.E. 1993. Arctic fox studies in the Prudhoe Bay Unit and adjacent undeveloped areas, 1992. Unpubl. report. Available at BP Exploration (Alaska) Inc., Environmental and Regulatory Affairs Dept., P.O. Box 196612, Anchorage, Alaska 99519, U.S.A.

BURGESS, R.M., STICKNEY, A.A., ROSE, J.R., and RITCHIE, R.J. 1990. Snow goose. 1989 Endicott environmental monitoring program. Unpubl. report. Available at BP Exploration (Alaska) Inc., Environmental and Regulatory Affairs Dept., P.O. Box 196612, Anchorage, Alaska 99519, U.S.A.

CHOATE, J.S. 1967. Factors influencing nesting success of eiders in Penobscot Bay, Maine. Journal of Wildlife Management 31:769-777.

COOKE, F., FINDLAY, C.S., and ROCKWELL, R.F. 1984. Recruitment and the timing of reproduction in lesser snow geese (Chen caerulescens caerulescens). Auk 101:451-458.

COOKE, F., ROCKWELL, R.F., and LANK, D.B. 1995. The snow geese of La Perouse Bay: Natural selection in the wild. New York: Oxford University Press. 297 p.

DAVIES, J.C., and COOKE, F. 1983. Annual nesting productivity in snow geese: Prairie droughts and arctic springs. Journal of Wildlife Management 47:291-296.

DWERNYCHUK, L.W., and BOAG, D.A. 1972. Ducks nesting in association with gulls - an ecological trap? Canadian Journal of Zoology 50:559-563.

EBERHARDT, L.E., GARROTT, R.A., and HANSON, W.C. 1983. Den use by arctic foxes in northern Alaska. Journal of Mammalogy 64:97-102.

EBERHARDT, L.E., HANSON, W.C., BENGTSON, J.S., GARROTT, R.A., and HANSON, E.E. 1982. Arctic fox home range characteristics in an oil development area. Journal of Wildlife Management 46:183-190.

EISENHAUER, J.H. 1977. Nesting ecology and behavior of Pacific brant in Alaska. M.S. thesis, University of Lethbridge, Alberta. $257 \mathrm{p}$.

ENSR CONSULTING AND ENGINEERING. 1992. Bioaccumulation of heavy metals, salts, and hydrocarbons in lower-trophic levels in the Prudhoe Bay and Kuparuk fields, 1988. Unpubl. report. Available at BP Exploration (Alaska) Inc., Environmental and Regulatory Affairs Dept., P.O. Box 196612, Anchorage, Alaska 99519, U.S.A.

HARWOOD, J. 1977. Summer feeding ecology of lesser snow geese. Journal of Wildlife Management 41:48-55.

JOHNSON, S.R. 1994a. The status of black brant in the Sagavanirktok River delta area, Alaska, 1991 -1993. Unpubl. report. Available at BP Exploration (Alaska) Inc., Environmental and Regulatory Affairs Dept., P.O. Box 196612, Anchorage, Alaska 99519, U.S.A.

- 1994b. The status of lesser snow geese in the Sagavanirktok River delta area, Alaska, 1980-1993. Unpubl. report. Available at BP Exploration (Alaska) Inc., Environmental and Regulatory Affairs Dept., P.O. Box 196612, Anchorage, Alaska 99519, U.S.A. 
1995. The status of snow geese in the Sagavanirktok River delta area, Alaska: 1994 monitoring program. Unpubl. report. Available at BP Exploration (Alaska) Inc., Environmental and Regulatory Affairs Dept., P.O. Box 196612, Anchorage, Alaska 99519, U.S.A.

JOHNSON, S.R., and HERTER, D.R. 1989. The birds of the Beaufort Sea. Unpubl. report. Available at BP Exploration (Alaska) Inc., Environmental and Regulatory Affairs Dept., P.O. Box 196612, Anchorage, Alaska 99519, U.S.A.

JOHNSON, S.R., TROY, D.M., and COLE, J.G. 1985. The status of snow geese in the Endicott Development Unit, Sagavanirktok River delta, Alaska: A 5-year summary report. Unpubl. report. Available at BP Exploration (Alaska) Inc., Environmental and Regulatory Affairs Dept., P.O. Box 196612, Anchorage, Alaska 99519, U.S.A.

JORGENSEN, M.T. 1988. Rehabilitation studies in the Kuparuk Oilfield, Alaska. Unpubl. report. Available at ARCO Alaska, Inc., P.O. Box 100360, Anchorage, Alaska 99510, U.S.A.

JORGENSON, M.T., and CATER, T.C. 1992. Bioremediation and tundra restoration after a crude oil spill near Drill Site 2U, Kuparuk Oilfield, Alaska. Unpubl. report. Available at ARCO Alaska, Inc., P.O. Box 100360, Anchorage, Alaska 99510, U.S.A.

KERBES, R.H., KOTANEN, P.M., and JEFFERIES, R.L. 1990. Destruction of wetland habitats by lesser snow geese: A keystone species on the west coast of Hudson Bay. Journal of Applied Ecology 27:242-258.

KIERA, E.F.W. 1984. Feeding ecology of black brant on the north slope of Alaska. In: Nettleship, D.N., Sanger, G.A., and Springer, P.F., eds. Marine birds: Their feeding ecology and commercial fisheries relationships. Canadian Wildlife Service Special Publication, Ottawa. 40-48.

LAWSON, D.E. 1986. Response of permafrost terrain to disturbance: A synthesis of observations from northern Alaska, U.S.A. Arctic and Alpine Research 18:1-17.

MacINNES, C.D., and MISRA, R.K. 1972. Predation on Canada goose nests at McConnell River, Northwest Territories. Journal of Wildlife Management 36:414-422.

MACKAY, J.R. 1970. Disturbances to the tundra and forest tundra environment. Canadian Geotechnical Journal 7:420-432.

MAKI, A.W. 1992. Of measured risks: The environmental impacts of the Prudhoe Bay, Alaska, oilfield. Environmental Toxicology and Chemistry 11:1691-1707.

McKENDRICK, J.D. 1986. Recording of tundra plant responses. Vol. III. In: Final wellsite cleanup on National Petroleum Reserve-Alaska. Unpubl. report. Available at U.S. Geological Survey, Office of the National Petroleum Reserve in Alaska, Anchorage, Alaska 99510, U.S.A.

MILNE, H., and REED, A. 1974. Annual production of fledged young from the eider colonies of the St. Lawrence estuary. Canadian Field-Naturalist 88:163-169.

MURPHY, S.M., and ANDERSON, B.A. 1993. Lisburne terrestrial monitoring program: The effects of the Lisburne development project on geese and swans, 1985-1989. Unpubl. report. Available at ARCO Alaska, Inc., P.O. Box 100360, Anchorage, Alaska 99510, U.S.A.

MURPHY, S.M., ANDERSON, B.A., and CRANOR, C.L. 1986. Lisburne terrestrial monitoring program, 1985: The effects of the Lisburne development project on geese and swans. Unpubl. report. Available at ARCO Alaska, Inc., P.O. Box 100360, Anchorage, Alaska 99510, U.S.A.

NOEL, L.E., SCHICK, C.T., and JOHNSON, S.R. 1996. Quantification of habitat alterations and bird use of impoundments in the Prudhoe Bay Oilfield, Alaska, 1994. Unpubl. report. Available at BP Exploration (Alaska) Inc., Environmental and Regulatory Affairs Dept., P.O. Box 196612, Anchorage, Alaska 99519, U.S.A.

PETERSEN, M.R. 1982. Breeding biology, habitat use, and productivity of geese at Kokechik Bay, Alaska, 1982. Unpubl. report. Available at U.S. Fish and Wildlife Service, 1011 Tudor Rd., Anchorage, Alaska 99503, U.S.A. 26 p.

RAVELING, D.G. 1989. Nest-predation rates in relation to colony size of black brant. Journal of Wildlife Management 53:87-90.

REEVES, H.M., COOCH, F.G., and MUNRO, R.E. 1976. Monitoring arctic habitat and goose production by satellite imagery. Journal of Wildlife Management 40:532-541.

SARGEANT, A.B., and RAVELING, D.G. 1992. Mortality during the breeding season. In: Batt, B.D.J., Afton, A.D., Anderson, M.D., Anthony, D.C., Johnson, D.H., Kadlec, J.D., and Krapu, G.L., eds. Ecology and management of breeding waterfowl. Minneapolis: University of Minnesota Press. 396-422.

SEDINGER, J.S., and FLINT, P.L. 1991. Growth rate is negatively correlated with hatch date in black brant. Ecology 72:496-502.

SEDINGER, J.S., LENSINK, C.J., WARD, D.H., ANTHONY, R.M., WEGE, M.L., and BYRD, G.V. 1993. Current status and recent dynamics of the black brant Branta bernicla breeding population. Wildfowl 44:49-59.

SENNER, R.G.B. 1989. Effects of petroleum operations in Alaskan wetlands. Unpubl. report. Available at ARCO Alaska, Inc., P.O. Box 100360, Anchorage, Alaska 99510, U.S.A.

STICKNEY, A.A., and RITCHIE, R.J. 1996. Distribution and abundance of brant (Branta bernicla) on the central arctic coastal plain of Alaska. Arctic 49:44-52.

STICKNEY, A.A., RITCHIE, R.J., ANDERSON, B.A., FLINT, D.A., BANYAS, P.W., and KING, J.G. 1993. Tundra swan and brant surveys on the arctic coastal plain, Colville River to Staines River, 1992. Unpubl. report. Available at ARCO Alaska, Inc., P.O. Box 100360, Anchorage, Alaska 99510, U.S.A.

SUMMERS, R.W., and UNDERHILL, L.G. 1987. Factors related to breeding production of brant geese Branta $b$. bernicla and waders (Charadrii) on the Taimyr Peninsula. Bird Study 34:161-171.

SYROECHKOVSKIY, Y.V., LITVIN, K. YE, and EBBINGE, B.S. 1991. Breeding success of geese and swans on Vaygach Island (USSR) during 1986-1988: Interplay of weather and arctic fox predation. Ardea 79:373-382.

TRUETT, J.C., and KERTELL, K. 1992. Tundra disturbance and ecosystem production: Implications for impact assessment. Environmental Management 16:485-494.

VERMEER, K., and ANWEILER, G.G. 1975. Oil threat to aquatic birds along the Yukon coast. Wilson Bulletin 37:467-481.

WALKER, D.A., and EVERETT, K.R. 1987. Road dust and its environmental impact on Alaskan taiga and tundra. Arctic and Alpine Research 19:479-489.

WALKER, D.A., WEBBER, P.J., BINNIAN, E.F., EVERETT, K.R., LEDERER, N.D., NORDSTRAND, E.A., and WALKER, 
146 - J.C. TRUETT et al.

M.D. 1987. Cumulative impacts of oilfields on northern Alaskan landscapes. Science 238:757-761.

WALKER, D.A., WEBBER, P.D., WALKER, M.D., LEDERER, N.D., MEEHAN, R.D., and NORDSTRAND, E.A. 1986. Use of geobotanical maps and automated mapping techniques to examine cumulative impacts in the Prudhoe Bay Oilfield, Alaska. Environmental Conservation 13:149-160. 